\title{
Александр ШУМИЛИН
}

\section{ФРАНЦИЯ: РЕСПУБЛИКА ПРОТИВ «ПОЛИТИЧЕСКОГО ИСЛАМА» (ЧАСТЬ I)}

\begin{abstract}
Аннотация. 16 февраля 2021 г. Национальное собрание Франции (нижняя палата парламента) одобрила проект закона о противодействии «сепаратизму». 30 марта этот документ должен обсуждаться членами Сената. Градус общественных дискуссий вокруг него начал нарастать сразу после выступления президента Э. Макрона 2 октября 2020 г. и последовавшей публикации в прессе основных положений проекта. Документ направлен на предотвращение радикализачии мусульманского сообщества Франции, на его более основательную адаптацию к общественно-политическим условиям и базовым иенностям Республики. Бо́льшая часть мусульманского сообщества и духовенства Франции одобрили предложения президента и правительства, а около трети мусульманских организаций выступили против. Последние, как правило, связаны с исламистской ассоииаџией «Братья-мусульмане», стремящейся расширить свои ячейки и сеть во Франции, да и в Европе в иеелом. Особенно отчётливо артикулируют установки «братьев» организации, легально действующие в турецєких общзинах Старого Света. Они на религиозном уровне воспроизводят и продолжают громкое словесное противостояние между Макроном и президентом Туриии Р.Т. Эрдоганом в октябре-ноябре минувшего года. В статье рассматривается стратегия франиузского правительства по противодействию попыткам радикальных исламистов легализовать фено́мен «политического ислама». Эта проблема, обострившаяся после терактов в ряде европейских стран в октябре 2020 г., стала сегодня для Франции не менее острой, чем борьба с пандемией.
\end{abstract}

Ключевые слова: Франиузская республика, сепаратизм, ислам, радикализм, законопроект, Национальное собрание, Макрон, Эрдоган.

Эти две проблемы - «политического ислама», как разновидности религиозного радикализма, и коронавируса - по сути, во многом схожи в своём разрушительном воздействии на общество: эпидемия поражает отдельных людей и целые группы населения (например, пожилого возраста), а активизация исламских радикалов в сфере политики неизбежно направлена на поражение, деструкцию всего общества, его традиций и устоев. Об остроте противостояния свидетельствуют длительность дебатов в Национальном собрании (135 часов) и результаты голосования: 347 депутатов высказались за проект президента и правительства, 151 - против, 65 - воздержались ${ }^{1}$. Не исключено, что в Сенате, где у партии Макрона нет большинства, прохождение законопроекта окажется ещё более трудным. Это не удивительно: глава МВД

(с) Шумилин Александр Иванович - доктор политических наук, главный научный сотрудник, руководитель центра «Европа - Ближний Восток» Отдела европейской безопасности, главный редактор Научно-аналитического вестника ИЕ РАН. Адрес: 125009, Россия, Москва, ул. Моховая, д. 11, стр.3.E-mail:mideast@bk.ru.

Статья поступила в редакичюю: 26.02.2021.

${ }^{1}$ French Lawmakers Approve Bill To Fight «Islamist Separatism». Agence France-Presse. 16.02.2021. URL: https:// www.ndtv.com/world-news/french-lawmakers-approve-bill-to-fight-islamist-separatism-2372035 (дата обращения 17.02.2021). 
Ж. Дарманин описал документ как «исключительно сильную светскую атаку (secular offensive)» (на сторонников политического ислама во Франции - А.Ш.), пояснив, что это «жёсткий текст, но необходимый для Республики» ${ }^{1}$.

\section{Светские ценности и «свобода слова»}

Свою программную речь, произнесённую 2 октября 2020 г. и посвящённую «борьбе с сепаратизмом», президент Макрон готовил долго, обсуждая её содержание с политиками, экспертами и исламоведами. Поскольку она касалась в основном проблемы исламизма во Франции, то все акценты в терминах и определениях были тщательно выверены. Главная забота президента в этом плане - обеспечить мирное сосуществование 5-миллионной (самой крупной в Европе) мусульманской общины с другими категориями французского населения на базе республиканских ценностей. «Мы должны бороться с исламистским сепаратизмом, - заявил президент. - Этот осознанный, теоретически обоснованный политико-религиозный проект материализуется в виде повторяющихся отклонений (его последователей - А.Ш.) от ценностей Республики, что выражается в формировании, по сути, параллельного (контр)общества (counter-society). Это следует из таких действий, как создание препятствий для посещения детьми (государственных - А.Ш.) школ, развитие отдельных спортивных и культурных программ на уровне коммун, которые используются для продвижения принципов, не соответствующих законам республики. Это идеологическая обработка и, как следствие, отрицание наших принципов, гендерного равенства и человеческого достоинства. Проблема в этой идеологии, которая утверждает, что её собственные законы выше законов республики»².

Французские власти предлагают сегодня самый радикальный и масштабный план решения одной из острейших проблем страны. Предшественники Макрона не решались на подобные действия - данная проблематика на протяжении последних десятилетий оставалась одной из наиболее актуальных и востребованных разве что в экспертной среде ${ }^{3}$.

Казалось бы, президент призвал бороться отнюдь не с исламом, а с его искажениями (основные тезисы ниже), за интересы всех граждан Республики, включая мусульман. И всё же речь вызвала противоречивую реакцию: поскольку она была произнесена до совершения во Франции двух наиболее громких за последнее время терактов (обезглавливания учителя в пригороде Парижа 16 октября и нападения на священников и паству в церкви Нотр-Дам в Ницце 29 октября), то политические оппоненты Макрона восприняли её как демарш властей в преддверии президентских выборов 2022 г., а некоторые и как «потворство крайне-правым группировкам» ${ }^{4}$. Между тем важно подчеркнуть, что «изложить свои мысли о секуляризме и исламе в широкой речи» Макрон обещал с первых дней своего пребывания в Елисейском дворце. А угроза исламистского терроризма сохранялась все его годы во власти 5 . Фраза же президента о том, что «ислам находится в состоянии кризиса во всём мире», вызвала протестную реакцию и в мусульманских странах, и в широких слоях исламской общины Франции.

\footnotetext{
${ }^{1}$ Ibid.

${ }^{2}$ Fight against separatism - the Republic in action: speech by Emmanuel Macron, President of the Republic, on the fight against separatism (Les Mureaux, 02.10.2020). The Ministry for Europe and Foreign Affairs (MEAE). URL: https:// www.diplomatie.gouv.fr/en/coming-to-france/france-facts/secularism-and-religious-freedom-in-france-63815/article/fig ht-against-separatism-the-republic-in-action-speech-by-emmanuel-macron (дата обращения 15.01.2021).

${ }^{3}$ Новоженова И.С. Франция: Ислам в светском государстве // Актуальные проблемы Европы. 2008. №1. С. 130145 .

${ }^{4}$ What's in France's draft law against «Islamist separatism»? Agence France-Presse. 16.02.2021. URL: https://www.fra nce24.com/en/live-news/20210216-what-s-in-france-s-draft-law-against-islamist-separatism (дата обращения 20.02. 2021).

5 Потемкина О.Ю. Европейский союз: война с терроризмом не окончена // Научно-аналитический вестник ИЕ PAH. 2020. №1. DOI: 10.15211/vestnikieran120202935
}

Научно-аналитический вестник ИЕ РАН, 2021, №1 
Последние увидели в предложениях Макрона «стигматизацию мусульман» как религиозной группы, а также намерение ограничить свободу слова в стране. Более того, часть общины сочла тезисы Макрона неуместными ещё и потому, что он, по их мнению, своими действиями «выталкивает мусульман на передовую линию внутриполитической борьбы во Франции» ${ }^{1}$. На этой волне широких возмущений и вступил в перепалку с французским президентом турецкий лидер Р.Т. Эрдоган ${ }^{2}$.

Для более яркого символизма законопроект был вынесен на рассмотрение Национального собрания 9 декабря 2020 г. - в день 115-й годовщины Закона о разделении Церквей и Государства 1905 г. Светский характер республики (laїсіté) считается одной из важнейших её ценностей. «Светскость - это цемент единой Франции, - пояснил Макрон. - Нам нельзя попадаться в западню, уготовленную экстремистами, которые стремятся стигматизировать мусульман» ${ }^{3}$. При этом важно подчеркнуть, что в тексте документа - в отличие от речи Макрона - не используется словосочетание «исламистский сепаратизм», чтобы избежать его восприятия как направленного против мусульман. Между тем в сопровождающем законопроект представлении правительства конкретно говорится о «радикальном исламизме». Перечислим основные положения нового подхода властей к данной проблеме, отражённые в проекте упомянутого закона.

Документ предлагает придать уголовный характер угрозам в адрес работников госсектора с целью принудить их делать изъятия из общепринятых правил и норм, такие, например, как учреждение раздельных плавательных бассейнов для мужчин и женщин. Также уголовной должна стать статья за «распространение ненависти» (hate speech): в новом законе власти должны иметь право быстро задерживать лиц, распространяющих в социальных сетях персональную информацию о госслужащих с целью нанесения им ущерба (реакция на обезглавливание учителя Сэмуэля Пати в октябре 2020 г.). Они могут быть осуждены на срок до трёх лет заключения и штраф до 45 тыс. евро. Документ подтверждает незыблемость «принципа нейтральности», согласно которому госслужащим запрещено носить религиозные символы, например, мусульманский платок, а также высказывать политические взгляды. Более того, теперь предлагается распространить этот принцип на сотрудников тех частных компаний, которые находятся в контрактных отношениях с госсектором. Далее законопроект учреждает более жёсткий режим контроля за финансовыми средствами, направляемыми религиозным организациям: последние должны будут раскрывать источники пожертвований свыше 10 тыс. евро.

Предполагается также ужесточить контроль над религиозными ассоциациями с тем, чтобы не допустить их попадания под влияние экстремистов. Наконец, проект закона резко сокращает возможности для обучения детей в домашних условиях (вне государственных школ), вводит более строгое наказание за «тесты на девственность», за принуждение к браку. Предлагается корректировка юридических норм для обеспечения равноправия мужчин и женщин при наследовании имущества (нормы шариата, заметим, традиционно выделяют преимущественное положение мужчин в этих вопросах).

Одной из наиболее чувствительных мер, прописанных в законопроекте, становится обязательность обучения в государственных образовательных учреждениях для всех детей с трёхлетнего возраста. Сегодня вне этих учреждений получают воспитание и образование 62

\footnotetext{
${ }^{1}$ Nussbaum A. Macron Thrusts Muslims Onto the Front Line of French Politics. Bloomberg. 13.12.2020. URL: https:// www.bloomberg.com/news/articles/2020-12-13/macron-thrusts-muslims-onto-the-front-line-of-french-politics (дата обращения 20.12.2020).

${ }^{2}$ См. подробнее: Шумилин А.И. Евросоюз-Турция: конфликтное партнёрство // Научно-аналитический вестник ИЕ РАН. 2020. №5. С. 7-15. DOI: 10.15211/vestnikieran320194853

${ }^{3}$ Fight against separatism - the Republic in action ...
}

Научно-аналитический вестник ИЕ РАН, 2021, №1 
тыс. детей. Проблема в том, что многие из них - особенно девочки-мусульманки - отданы в частные заведения, нередко радикальной направленности. По словам Макрона, «школы прежде всего должны вселять ценности Республики, а не какой-то религии, воспитывать граждан, а не поклонников пророков» ${ }^{1}$. Наблюдатели склонны полагать, что власти не будут проявлять чрезмерной жёсткости в этом вопросе и пойдут на компромисс с родителями. Те, однако, должны будут обращаться за разрешением к властям обучать своих детей в особых условиях и могут получить отказ. При этом по медицинским показателям обучение детей вне государственных школ и учреждений останется возможным в прежнем масштабе.

\section{«Хартия принципов» раскалывает мусульман Франции}

Другой аспект законопроекта, вызывающий наибольший общественный резонанс, - взаимодействие государства с религиозными организациями. Правительство считает необходимым провести консультации с руководством исламских ассоциаций, которые получают ассигнования из госбюджета. По словам Марлен Шиаппа, госсекретаря по вопросам гендерного равенства, «ни один евро из госбюджета не должен попасть в руки врагов Республики» ${ }^{2}$.

Впрочем, выделение бюджетных средств, судя по всему, как раз и рассматривается правительством как эффективный рычаг нормализации взаимодействия с религиозными (точнее - исламскими) организациями. Главная задача властей в этом отношении - перекрыть каналы «иностранного вмешательства» в дела мусульманских общин и ассоциаций во Франции. И проблема далеко не сводится только к денежным потокам из-за границы. Важнее, что одновре́менно с финансовыми вливаниями различные исламские центры направляют во Францию своих служителей, богословов и мулл, которые и становятся распространителями таких интерпретаций Корана, которые просто граничат с экстремизмом. Этим объясняется сформулированное разработчиками законопроекта предложение создать в стране самостоятельный, независимый от внешних сил центр подготовки проповедников.

Ровно год назад - 15 февраля 2020 г. - авторитетный французский журнал Le Point oпубликовал выдержки из якобы полученного неофициально из правительственных кругов 31страничного документа под названием «Стратегия борьбы против исламизма и покушений на республиканские принципы» ${ }^{3}$. В нём впервые упоминалась необходимость положить конец системе «прикомандированных имамов» (les Imams détachés) из Марокко, Алжира и Турции, о чём на тот момент уже проводились переговоры с правительствами этих стран. Более того, по появившейся в прессе информации, правительство намерено выслать из страны порядка 300 имамов из упомянутой категории ${ }^{4}$ Вместо «ввозимых» имамов таковые должны, по мнению Парижа, готовиться на специальных курсах при французских университетах, а не при исламских центрах, финансируемых различными странами: властей насторожил тот факт, что только за период с 2016 по 2018 гг. в этих центрах число обучающихся подскочило на $60 \% 5$. Положение о проведении такой реорганизации заложено в законопроект. С этой целью правительство намерено достичь взаимопонимания на основе подписания с руководством исламских организаций «Хартии Принципов», что станет основанием для продолжения их финан-

\footnotetext{
${ }^{1}$ Here's all you need to know about France's controversial separatism law. Euronews.com. 16.02.2021. URL: https:// www.euronews.com/2021/02/16/here-s-what-you-need-to-know-about-france-s-controversial-separatism-law (дата обращения 20.02.2021).

Ibid.

${ }^{3}$ Cordelier J. Communautarisme: la feuille de route du gouvernement. Le Point. 15.02.2020. URL: https://www.lepoint. fr/politique/exclusif-communautarisme-la-feuille-de-route-du-gouvernement-15-02-2020-2362821_20.php\# (дата обращения 19.02.2021).

${ }^{4}$ Macron hails French Muslim council charter to combat extremism. France 24. 18.01.2021. URL: https://www.france24. com/en/france/20210118-french-muslim-council-draws-up-charter-to-combat-extremism (дата обращения 20.02.2021). ${ }^{5}$ Ibid.
}

Научно-аналитический вестник ИЕ РАН, 2021, №1 
сирования со стороны государства. Документ из 10 пунктов назван Макроном «основополагающим текстом для определения отношений между Государством, Исламом и Францией» 1 .

18 января 2021 г. после многомесячных дискуссий представители шести из девяти федераций, входящих во ФСИВ (Французский Совет Исламского Вероисповедания - French Council of the Muslim Faith) дали согласие на подписание Хартии, в тексте которой отражена их приверженность базовым принципам Французской Республики и отказ от использования ислама в политических целях (в тексте фигурирует термин «инструментализация ислама»).

В документе подчёркивается, что ислам и ценности Республики «полностью совпадают», акцентируется особая значимость отделения религии от государства ${ }^{2}$. Эти шесть федераций взяли на себя обязательство учредить Национальный совет имамов, который будет курировать процесс подготовки служителей мечетей во Франции. Остальные три крупных организации пока воздерживаются от подписания документа, что отчётливо свидетельствует о серьёзном расколе в мусульманской среде страны. Это Координационный комитет турецких мусульман во Франции (ККТМФ), Исламская конфедерация Милли Горюс (ИКМГ) и Движение за веру и практику (ДВП).

Анализ аргументов руководителей этих организаций-«отказников» подводит к выводу о том, что их возражения носят не только принципиальный характер, но и дают основания для их интерпретации как близких к радикализму. В один голос они называют Хартию «антимусульманским документом». Почему? Потому что (и это общий тезис «отказников») власти «не дают мусульманам жить своей жизнью», пытаются «подменить исламские ценности ценностями французскими». Толковать подобное можно однозначно: руководство и сторонники упомянутых организаций настаивают на праве и, что особенно важно, обязанности мусульман демонстрировать религиозные символы в общественных местах, соблюдать повсеместно требования пятикратного моления в течение дня и т.д. Так, например, руководитель ККТМФ Ибрагим Алчи утверждает следующее: «Исламская религия, которая основывается на Коране и Сунне, не может быть сведена к (требованиям - А.Ш.) какого-либо общества и идеологическому дискурсу. Ислам - религия универсальная» ${ }^{3}$. Подобные утверждения авторитетов упомянутых трёх организаций сокращают пространство компромисса, достигнутого властями с шестью другими федерациями, входящими в состав ФСИВ.

Примечательно, что три организации-«отказники» действуют в основном в турецких общинах Франции (а также и ряда других стран ЕС) и склонны придерживаться канонов и трактовок Корана, выработанных турецкими богословами. Фундаментальная проблема, однако, в том, что эти «турецкие» трактовки зачастую не просто вдохновлены установками, характерными для международной ассоциации «Братья-мусульмане» (БМ), но во многом их воспроизводят и копируют. Сама же ассоциация БМ, несмотря на ряд аспектов её учения, считающихся в либеральных кругах ЕС «модернизаторскими», была и остаётся воплощением «политического ислама». Доктрина «братьев» нацелена на утверждение доминирования ислама в государстве и обществе, на создание исламского государства всеми возможными способами, в том числе и через участие в избирательном процессе. Ярким примером утверждения БМ во власти через выборы стали Тунис (партия «Ан-Нахда» обеспечила себе большинство в парламенте) и Египет (президентом страны в 2012 г. был избран Мухаммед Мурси, свергнутый год спустя).

\footnotetext{
${ }_{2}^{1}$ Fight against separatism - the Republic in action...

2 Bermingham, P-P. France issues charter for imams meant to fight 'political Islam'. Politico. 18.01.2021. URL: https://www.politico.eu/article/france-political-islam-charter-imams-fight/ (дата обращения 20.01.2021).

${ }_{3}^{3}$ Turkish Muslim groups in France oppose anti-Islam bill. Daily Sabah. 10.02.2021. URL: https://www.dailysabah. com/politics/diplomacy/turkish-muslim-groups-in-france-oppose-anti-islam-bill (дата обращения 15.02.2021).
} Научно-аналитический вестник ИЕ РАН, 2021, №1 
Так складывается ситуация в мусульманской общине Франции в один из самых значимых периодов её жизни. Положение усугубляется вполне откровенным вмешательством внешних сил - основных центров ислама в странах Ближнего Востока. Активнее других демонстрирует свою заинтересованность в этом вопросе турецкий президент Р.Т. Эрдоган: в начале февраля 2021 г. он обвинил политиков стран ЕС в пренебрежительном отношении к исламу, в игнорировании усиления антиисламских настроений там и призвал «турецкие институции переходить к конкретным действиям в вопросах, связанных с положением мусульман и турок в этих странах (Евросоюза - А.Ш.)»»

Предложенный президентом и правительством законопроект, направленный на противодействие сепаратизму, может стать основой для самой радикальной и масштабной реформы в сфере межрелигиозных отношений в послевоенной Франции. Задача властей - кодифицировать отношения между религиозными общинами и государством с чётким приоритетом принципа светскости как основы республиканского строя. В случае успеха французский опыт может стать модельным для других стран Евросоюза. На данный момент, однако, законопроект оказался фактором раскола внутри мусульманских общин Франции. Сторонники организаций, несогласных с позицией правительства, выражают взгляды, которые могут быть квалифицированы как радикальные и граничащие с экстремизмом. В основном это группы мусульман внутри турецких общин. В поддержку своих жёстко настроенных единоверцев во Франции всё чаще высказывается президент Турции Р.Т. Эрдоган. Таким образом, формально внутренняя проблема Франции может резонировать далеко за её пределами. Этому аспекту автор рассчитывает посвятить продолжение в следующем выпуске Научно-аналитического вестника.

\section{Список литературы}

Борко Ю.А., Биссон Л.С. Европейская интеграция: перезапуск идеи «Социальной Европы» // Современная Европа. 2019. №6. C. 5-17. DOI: 10.15211/soveurope620190517

Новоженова И.С. Франция: Ислам в светском государстве // Актуальные проблемы Европы. 2008. №1. С. 130-145.

Потемкина О.Ю. Европейский союз: война с терроризмом не окончена // Научно-аналитический вестник ИЕ РАН. 2020. №1. DOI: 10.15211/vestnikieran120202935

Шумилин А.И. Евросоюз-Турция: конфликтное партнёрство // Научно-аналитический вестник ИЕ РАН. 2020. №5. С. 7-15. DOI: 10.15211/vestnikieran320194853

\section{References}

Bermingham, P.-P. (2021) France issues charter for imams meant to fight «political Islam». Politico. January 18, 2021. Available at: https://www.politico.eu/article/france-political-islam-charterimams-fight/ (accessed 20.01.2021).

Borko, Ju.A., Bisson, L.S. (2019). Evropejskaja integracija: perezapusk idei «Social'noj Evropy» [European Integration: A Restart of the Idea of «Social Europe»]. Sovremennaja Evropa [Contemporary Europe]. 6. P. 5-17. (In Russian). DOI: 10.15211/soveurope620190517

\footnotetext{
${ }^{1}$ Camii A.H. West fails to act against rising anti-Islam sentiment: Erdoğan. Daily Sabah. 10.02.2021. URL: https:// www.dailysabah.com/politics/west-fails-to-act-against-rising-anti-islam-sentiment-erdogan/news (дата обращения 22.02.2021).
} 
Camii, A.H. (2021). West fails to act against rising anti-Islam sentiment: Erdoğan. Daily Sabah. February 10, 2021. Available at: https://www.dailysabah.com/politics/west-fails-to-act-againstrising-anti-islam-sentiment-erdogan/news (accessed 22.02.2021).

Cordelier, J. (2021). Communautarisme: la feuille de route du gouvernement. Le Point. February 15, 2021. Available at: https://www.lepoint.fr/politique/exclusif-communautarisme-la-feuille-deroute-du-gouvernement-15-02-2020-2362821_20.php\# (accessed 19.02.2021). (In French).

Fight against separatism - the Republic in action: speech by Emmanuel Macron, President of the Republic, on the fight against separatism (Les Mureaux, 02 Oct. 2020). The Ministry for Europe and Foreign Affairs (MEAE). Available at: https://www.diplomatie.gouv.fr/en/coming-to-france/ france-facts/secularism-and-religious-freedom-in-france-63815/article/fight-against-separatism-therepublic-in-action-speech-by-emmanuel-macron (accessed 15.01.2021).

French Lawmakers Approve Bill To Fight «Islamist Separatism». Agence France-Presse. February 16, 2021. Available at: https://www.ndtv.com/world-news/french-lawmakers-approve-bill-tofight-islamist-separatism-2372035 (accessed 17.02.2021).

Here's all you need to know about France's controversial separatism law. Euronews.com. February 16, 2021. Available at: https://www.euronews.com/2021/02/16/here-s-what-you-need-toknow-about-france-s-controversial-separatism-law (accessed 20.02.2021).

Macron hails French Muslim council charter to combat extremism. France 24. February 21, 2021. Available at: https://www.france24.com/en/france/20210118-french-muslim-council-drawsup-charter-to-combat-extremism (accessed 20.02.2021).

Novozhenova, I.S. (2008). Francija: Islam v svetskom gosudarstve [France: Islam in secular state]. Aktual'nye problemy Evropy [Current problems of Europe]. 1. P. 130-145. (In Russian).

Nussbaum, A. Macron Thrusts Muslims Onto the Front Line of French Politics. Bloomberg. December 13, 2020. Available at: https://www.bloomberg.com/news/articles/2020-12-13/macronthrusts-muslims-onto-the-front-line-of-french-politics (accessed 20.12.2020).

Potemkina, O.Ju. (2020). Evropejskij sojuz: vojna s terrorizmom ne okonchena [European Union: the war with terrorism is not over]. Nauchno-analiticheskij vestnik IE RAN [[Scientific and Analytical Herald of the IE RAS]. 1. P. 29-35. (In Russian). DOI: 10.15211/vestnikieran120202935

Shumilin, A.I. (2020). Evrosojuz-Turcija: konfliktnoe partnjorstvo [European Union - Turkey: Conflict Partnership]. Nauchno-analiticheskij vestnik IE RAN [[Scientific and Analytical Herald of the IE RAS]. 5. P. 7-15. (In Russian). DOI: 10.15211/vestnikieran320194853

Turkish Muslim groups in France oppose anti-Islam bill. Daily Sabah. February 10, 2021. Available at: https://www.dailysabah.com/politics/diplomacy/turkish-muslim-groups-in-france-opposeanti-islam-bill (accessed 15.02.2021)

What's in France's draft law against «Islamist separatism»? Agence France-Presse. February 16, 2021. Available at: https://www.france24.com/en/live-news/20210216-what-s-in-france-s-draftlaw-against-islamist-separatism (accessed 20.02.2021).

\section{France: Republic against «Political Islam» (Part I)}

Author. Alexander Shumilin, Doctor of Political Sciences, Chief Research Associate, Head of the Center «Euro-Atlantic - the Middle East» of the European Security Department, Editor -inChief of the Scientific Analytical Herald at the Institute of Europe, Russian Academy of Sciences. Address: 11-3, Mokhovaya str., Moscow, Russia, 125009. E-mail: mideast@bk.ru.

Abstract. On February 16, 2021, the French National Assembly (lower house of parliament) approved a draft law on countering separatism. On March 30, this document is to be discussed by members of the Senate. The degree of public discussions around him began to grow immediately 
after the speech of President E. Macron on October 2, 2020 and the subsequent publication in the press of the main provisions of the project. In fact, the document is aimed at preventing the radicalization of the Muslim community of France, at its more thorough adaptation to the socio-political conditions and basic values of the Republic. Most of the Muslim community and the clergy of France approved the proposals of the president and the government, while about a third of Muslim organizations opposed them. The last, as a rule, are linked to the international Islamist association «Muslim Brotherhood», which seeks to expand its cells and network in France, and in Europe as a whole. Organizations operating legally in the Turkish communities of the Old World articulate especially clearly the attitudes of the «brothers». In fact, at the religious level, they reproduce and continue the loud verbal confrontation between Macron and Turkish President R.T. Erdogan in October-November last year. The article examines the strategy of the French government to counter the attempts of radical Islamists to legalize the phenomenon of «political Islam». This problem, aggravated after the terrorist attacks in a number of European countries in October 2020, has become no less acute for France today than the fight against the pandemic.

Key words: French Republic, separatism, Islam, radicalism, bill, National Assembly, Macron, Erdogan.

DOI: http://dx.doi.org/10.15211/vestnikieran120215461 